\title{
Deference and Due Process
}

\section{Citation}

Adrian Vermeule, Deference and Due Process (May 27, 2015).

\section{Permanent link}

http://nrs.harvard.edu/urn-3:HUL.InstRepos:16151193

\section{Terms of Use}

This article was downloaded from Harvard University's DASH repository, and is made available under the terms and conditions applicable to Open Access Policy Articles, as set forth at http:// nrs.harvard.edu/urn-3:HUL.InstRepos:dash.current.terms-of-use\#OAP

\section{Share Your Story}

The Harvard community has made this article openly available.

Please share how this access benefits you. Submit a story.

Accessibility 


\title{
Deference and Due Process
}

\author{
Adrian Vermeule
}

"Since procedural decisions should be made to serve the substantive task, it follows that expertness in matters of substance [is] relevant to the exercise of procedural discretion."

Louis Jaffe, Judicial Control of Administrative Action 567 (1965)

"Using modern due process analysis, the Agency, in the second step of its Chevron analysis, carefully weighed the risks and benefits of informal hearing procedures ... determining that these procedures would not violate the Due Process Clause of the Constitution."

Environmental Protection Agency, Amendments to Streamline the National Pollutant Discharge Elimination System Program Regulations: Round Two, 65 Fed. Reg. 30886, 30898 (2000), appeal dismissed, Dominion Energy Bracton Point LLC v. Johnson, 443 F.3d 12 (2006).

In the textbooks, procedural due process is a strictly judicial enterprise. ${ }^{1}$ As the story runs, the Court in Mathews v. Eldridge ${ }^{2}$ settled on a balancing test for determining what process is due, while in Cleveland Board of Education v. Loudermill ${ }^{3}$ the Court finally decided that while the political branches may determine substantive entitlements, it is for courts to decide independently what process the Constitution requires. The notion that procedural due process might be committed primarily to the discretion of the agencies themselves is almost entirely absent from the literature.

\footnotetext{
${ }^{1}$ See, e.g., Stephen G. Breyer, Richard B. Stewart, Cass R. Sunstein, Adrian Vermeule \& Michael Herz, Administrative Law and Regulatory Policy 675 (7th ed. 2011) ("[W]hile legislatures are free to define the substantive content of property entitlements, the due process clause gives the judiciary an independent and final say on the adequacy of the procedures for determining and vindicating those entitlements."); Ronald A. Cass, Colin S. Diver, Jack M. Beermann \& Jody Freeman, Administrative Law 616 (6th ed. 2011) (describing administrative due process cases as two-step inquiries for courts); see generally Richard J. Pierce, Jr., Sidney A. Shapiro, and Paul R. Verkuil, Administrative Law and Process 237-47 (6th ed. 2014).

${ }^{2} 424$ U.S. 319 (1976).

3470 U.S. 532, 541 (1985) ("“The right to due process is conferred, not by legislative grace, but by constitutional guarantee.").
} 
The facts on the ground are very different. Thanks to converging strands of caselaw after Mathews -- partly involving due process, partly involving post-Chevron cases on agency interpretation of procedural provisions, and partly involving the long shadow of Vermont Yankee v. NRDC ${ }^{4}$ and its latest incarnation, Perez v. Mortgage Bankers $^{5}$-- agencies themselves are now the primary front-line expositors and appliers of the Mathews test. Administrative constitutionalism ${ }^{6}$ has already come to the Due Process Clause. ${ }^{7}$

In the second epigraph, the Environmental Protection Agency, referring to itself in the third person, solemnly determined that it had correctly applied the Mathews factors to decide how much procedure to afford in a class of permit decisions. ${ }^{8}$ (The epigraph also shows how closely the due process issues are entangled with questions of Chevron deference, when agencies are interpreting procedural provisions in organic statutes. I will disentangle all that later). Similar examples are legion, arising from all sectors of the administrative state. The Nuclear Regulatory Commission applied Mathews to formulate rules of procedure for licensing of plant operators. ${ }^{9}$ The Bureau of Alcohol, Tobacco and Firearms applied Mathews to decide whether it should use formal hearings in the denial or revocation of "certificates of label approval" for alcohol. ${ }^{10}$ The Treasury Department applied Mathews to decide how much procedure to afford when deciding whether to revoke certificates of surety upon complaint from agencies. ${ }^{11}$ The Centers for Disease Control even applied Mathews in a proposed rule to determine procedures for quarantine of travelers suspected of carrying a communicable disease, although the rule was never made final. ${ }^{12}$ There are examples from the Department of

\footnotetext{
${ }^{4} 435$ U.S. 519 (1978).

5 135 S. Ct. 1199 (2015).

${ }^{6}$ For indispensable treatments of constitutional interpretation by agencies, see Gillian E. Metzger, Administrative Constitutionalism, 91 Tex. L. Rev. 1897 (2015); id. at 1900 (asking whether administrative procedure counts as administrative constitutionalism); Sophia Z. Lee, Race, Sex, and Rulemaking: Administrative Constitutionalism and the Workplace, 1960 to the Present, 96 Va. L. Rev. 799 (2010).

${ }^{7}$ I refer only to the Due Process Clause of the Fifth Amendment, and will address only due process claims against federal agencies. Although a few of the relevant cases have involved state agencies, see, e.g., Goldberg v. Kelly, 397 U.S. 254 (1970), the central lines of precedent I will address have all arisen in a federal setting, and state agencies present distinctive problems that I bracket here.

${ }^{8}$ Environmental Protection Agency, Amendments to Streamline the National Pollutant Discharge Elimination System Program Regulations: Round Two, 65 Fed. Reg. 30886, 30898 (2000), appeal dismissed, Dominion Energy Bracton Point LLC v. Johnson, 443 F.3d 12 (2006).

${ }^{9}$ Informal Hearing Procedures for Nuclear Reactor Operator Licensing Adjudications, 55 Fed. Reg. 36801-01, 36802 - 03 (Sept. 7, 1990) (codified at 10 C.F.R. pt. 2). See also Changes to Adjudicatory Process, 69 Fed. Reg. 2182-01 (Jan.14, 2004) (codified at 10 C.F.R. pt. 2) (explaining that informal hearing procedures are consistent with constitutional due process).

${ }^{10}$ Procedures for the Issuance, Denial, and Revocation of Certificates of Label Approval, Certificates of Exemption From Label Approval, and Distinctive Liquor Bottle Approvals (93F-029P), 64 Fed. Reg. 212201, 2124 - 25 (Jan. 13, 1999) (codified at 27 C.F.R. pt.

11 Surety Companies Doing Business With the United States, 79 Fed. Reg. 61992-01, 61996 - 97 (Oct. 16, 2014) (codified at 31 C.F.R. 223.20).

${ }^{12}$ Control of Communicable Diseases, 70 Fed. Reg. 71892-01, 71895 - 96 (Nov. 30, 2005).
} 
Labor, ${ }^{13}$ from the immigration agencies, ${ }^{14}$ from the Labor Board,${ }^{15}$ the $\mathrm{FEC},{ }^{16} \mathrm{HUD},{ }^{17}$ and on and on -- anywhere and everywhere. Descriptively, agencies are the first to apply the marginalist cost-benefit approach to due process.

The courts, for their part, have no settled approach to such decisions, despite the confident outlines of procedural due process law to be found in the hornbooks. Some agency applications of Mathews are apparently never reviewed in court at all, leaving the agency as both the first and last body to apply the test. When cases do reach court, the law in action is inconsistent. Nominally speaking, the conventional wisdom is that courts are supposed to apply Mathews independently, ${ }^{18}$ and some cases do just that. Others emphasize language in Mathews that requires deference to legislative or administrative judgments about what process is due in a given domain -- a strand whose relationship to the standard framework of procedural due process is undertheorized, to say the least. Another line of cases slices the same pie differently, saying that where deference is appropriate, Mathews does not apply in the first place -thereby preserving the nominal independence of the test, but only by contracting its domain. Finally, there are many cases that apply Mathews without any express or acknowledged deference, but in a fashion that can only be described as cursory, implicitly crediting agency assertions unless they are patently unreasonable. Overall, whatever form deference may take, the caselaw reviews agency determinations about due process with a light hand.

That judicial posture of deference is exactly right, or so I will argue. ${ }^{19}$ Rather than decide for themselves "what process is due," courts should ask only whether the agency

\footnotetext{
${ }^{13}$ Regulations Implementing the Federal Coal Mine Health and Safety Act of 1969, as Amended, 64 Fed. Reg. 54966-01, 54994 - 95 (proposed Oct. 8, 1999) (codified at 20 C.F.R. 725.414).

${ }^{14}$ Board of Immigration Appeals: Procedural Reforms To Improve Case Management, 67 Fed. Reg. 54878-01, 54881 - 82 (Aug. 26, 2002) (codified at 8 C.F.R. pt. 3); Executive Office for Immigration Review; Board of Immigration Appeals: Streamlining, 64 Fed. Reg. 56135-01, 56137 - 39 (Oct. 18, 1999) (codified at 8 C.F.R. pt. 3); Administrative Deportation Procedures for Aliens Convicted of Aggravated Felonies Who Are Not Lawful Permanent Residents, 60 Fed. Reg. 43954-01, 43955 - 57 (Aug. 24, 1995) (codified at 8 C.F.R. 242).

${ }^{15}$ Representation-Case Procedures, 79 Fed. Reg. 74308-01, 74371 - 73 (Dec. 15, 2014) (codified at 29 C.F.R. 102.63).

${ }^{16}$ Administrative Fines, 65 Fed. Reg. 31787-01, 31787 - 88 (May 19, 2000) (codified at 11 C.F.R. pts. 104, 111).

17 Single Family Mortgage Insurance; Appraiser Roster Removal Procedures, 65 Fed. Reg. 17974-01, 17974 - 75 (Apr. 5, 2000) (codified at 24 C.F.R. pt. 200).

${ }^{18}$ See sources cited in $\mathrm{n} .1$, supra.

${ }^{19}$ I believe the theory offered here is novel in the academic literature, although is already reflected in (part of) the caselaw. Others have briefly mentioned similar arguments. See Thomas W. Merrill, The Accardi Principle, 74 Geo. Wash. L. Rev. 569, 609 - 10 (2006) (noting a possible regime in which judicial review of agency choice of procedures would be "limited to cases in which the agency choice of procedures can be said to be plainly unreasonable. Mathews would not be overruled, but merely reinterpreted as requiring significant deference to agency choice of procedures," id. at 610); Gillian Metzger, Ordinary Administrative Law as Constitutional Common Law, 110 Colum. L. Rev. 479, 507 n. 99 (2010) (although
} 
offered a rational justification for providing whatever process it did choose to provide. Although courts should continue to apply the reigning Mathews calculus, according to which the process that is due is a function of the (marginal) risks and costs of error and of procedural safeguards, courts should not independently assess what the Mathews calculus requires in the circumstances. Rather they should defer to reasonable agency decisions about the design of procedural arrangements, reviewing the agency's choices for arbitrariness, but not correctness. Although the Mathews calculus will supply the governing legal norm, courts will relegate themselves to the institutional margins, reviewing agencies' execution of the Mathews calculus rather than performing it themselves.

Viewed from one angle, the theory is radical; from another, it attempts to make coherent sense of a number of converging strands of recent caselaw, and is in that sense conventional. The theory is radical insofar as it implies a greatly reduced role for courts in overseeing agency procedural choices under the rubric of procedural due process. In a Dworkinian spirit, however, the theory attempts to combine justification, the best account of the principles underlying the precedents, with fit, a coherentist account of the law's path in recent decades. ${ }^{20}$ Dworkinism tends to be associated with the expansion of Law's Empire, ${ }^{21}$ but that is a strictly contingent association, stemming in part from Dworkin's own proclivities. ${ }^{22}$ Fit-and-justification may just as well counsel abnegation of authority by law in favor of administrative bodies; I will suggest that it does exactly that in this setting.

On the dimension of fit, surrounding developments in the law since Mathews was decided in 1976 support a reduced due process role for courts. Those developments include (1) the "very basic tenet of administrative law that agencies should be free to fashion their own rules of procedure," announced by the Supreme Court in Vermont Yankee, ${ }^{23}$ two years after Mathews, and recently reaffirmed in Perez v. Mortgage Bankers $^{24}$; (2) the watershed of Chevron ${ }^{25}$, decided in 1984, and its key premises that on grounds of both expertise and accountability, agencies are better positioned than

procedural due process is an independent question for the courts, the Mathews test takes "the government's provided procedures as the baseline against which additional requirements must be justified.").

${ }^{20}$ Cf. Ronald Dworkin, Law's Empire 255 (1986); Ronald Dworkin, Hard Cases, 88 Harv. L. Rev. 1057 (1975).

${ }^{21}$ See Dworkin, Law's Empire 407 ("The courts are the capitals of law's empire, and judges are its princes ....").

${ }^{22}$ David Dyzenhaus observes that -- quite remarkably -- Dworkin's account of adjudication leaves very little room for the administrative state. David Dyzenhaus, "The Rule of Law as the Rule of Liberal Principle," in Arthur Ripstein, ed., Ronald Dworkin (Cambridge 2007) at 71 - 72. It is as though Dworkin's mental world contained courts and legislatures and little else.

${ }^{23}$ Vermont Yankee Nuclear Power Corp. v. Natural Res. Def. Council, Inc., 435 U.S. 519, 544 (1978).

24135 S. Ct. 1199 (2015).

${ }^{25}$ Chevron, U.S.A., Inc. v. Natural Resources Defense Council, Inc., 467 U.S. 837 (1984). 
courts to interpret governing statutes; (3) the growing body of caselaw that affords agencies Chevron deference even on procedural provisions in organic statutes ${ }^{26}--$ a body of caselaw that has witnessed agencies taking charge of the Mathews calculus, and that squarely rejects due process counterarguments; and (4) the Court's recent emphatic pronouncement that under Chevron, agencies may even be entrusted with power to determine the scope of their own jurisdiction. ${ }^{27}$ Last but certainly not least (5) a number of post-Mathews due process cases explicitly or implicitly expand upon Mathews' own cryptic suggestion that 'in assessing what process is due in this case, substantial weight must be given to the good-faith judgments of the individuals charged by Congress" ${ }^{\prime 2}$ with administering the relevant statutes. ${ }^{29}$ Although in principle courts do not defer to agencies on the application of the Mathews calculus, this body of caselaw shows that sometimes deference of that sort does occur -- and I believe for good reason.

On the dimension of justification, I suggest that these converging developments in the caselaw after Mathews rest on a master principle, the one identified by Louis Jaffe in the first epigraph: for many of the same reasons that agencies are better positioned than courts to interpret the procedural provisions contained in their organic statutes, agencies are also better positioned than courts to assess the marginal costs and benefits of additional increments of procedure for program beneficiaries and regulated actors, as Mathews requires. The traditional lawyer's instinct is to say that procedural questions are for courts, especially when the relevant procedure is in some sense constitutionally mandated. But these instinctive commitments no longer reflect the governing premises on which the law operates. Rather the law now takes into account the interdependence of procedure and substance, and understands that agency choice of procedures is an exercise in system design, which must allocate risks of error and determine the marginal benefits and costs of decisionmaking in light of administrative goals. Generalist courts, who observe the system only episodically, should play a subsidiary reviewing role, asking only whether the agency's procedural choices are rationally defensible.

\section{Background}

The Mathews Calculus

Procedural due process has a long history before Mathews was decided in 1976, and I will advert to that history where relevant. Under the nominally prevailing current doctrine, however, there are three analytic steps in any procedural due process

\footnotetext{
${ }^{26}$ See infra TAN $84-88$.

27 See infra TAN 89 - 97.

${ }^{28}$ Mathews v. Eldridge, 424 U.S. 319, 349 (1976).

${ }^{29}$ See infra TAN $48-60$.
} 
challenge to administrative action. In some presentations, some of the following steps may be expressed differently, subdivided or put in a different order; but the law ends up in much the same place anyway.

First, the court must identify a protected interest in "life, liberty or property." There is a separate, elaborate body of law that addresses the problem of protected interests, ${ }^{30}$ but I will bracket this set of questions, which were not relevant in Mathews and are not my topic here. There is one large qualification to this bracketing, however: I will have to address protected interests to identify one very large red herring dragged across the path of the law -- the idea that due process claimants must "take the bitter with the sweet," once urged by then-Justice Rehnquist. ${ }^{31}$

Second, the court must ask whether there has been a "deprivation" of a protected interest. Here too there is a body of law detailing what counts as a "deprivation" (or alternatively: which deprivations are constitutionally actionable). The major line is between intentional and negligent government action inflicting harm on protected interests; negligent action, even if tortious, does not amount to a deprivation (or a constitutionally actionable one). ${ }^{32}$

Third, given the deprivation of a protected interest, the court must decide what process is due. Here there is a critical distinction between agency action that is legislative in character (rulemaking), and agency action that is court-like (adjudication). An adjudicative hearing is not constitutionally required for legislative action by agencies, meaning action that applies in a generalized fashion across regulated actors, rather than applying on the basis of particular features of specific parties. ${ }^{33}$ For general rulemaking, legislative process just is all the process that the Constitution affords, although of course the Administrative Procedure Act may require more.

As to adjudicative action by agencies, the basic requirement of due process is "some kind of hearing." 34 The elements of the required hearing vary with circumstances and are highly contextual. In some cases, a traditional formal judicial-type hearing on the record will be required; in others, an informal paper hearing, without argument or testimony, may well be sufficient. The timing of hearings also varies; due process does

\footnotetext{
${ }^{30}$ See, e.g., Bd. of Regents v. Roth, 408 U.S. 564 (1972); Perry. v Sindermann, 408 U.S. 593 (1972); Goldberg v. Kelly, 397 U.S. 254 (1970); Wisconsin v. Constantineau, 400 U.S. 433 (1971); Paul v. Davis, 474 U.S. 693 (1976). See also Peter L. Strauss et al., Gellhorn \& Byse's Administrative Law 812 (10th ed. 2003).

${ }^{31}$ Arnett v. Kennedy, 416 U.S. 134, 154 (1974) (plurality opinion).

32 See, e.g., Daniels v. Williams, 474 U.S. 327 (1986).

33 See Minnesota State Bd. for Community Colleges v. Knight, 465 U.S. 271 (1984); Bi-Metallic Investment Co. v. State Bd. of Equalization, 239 U.S. 441 (1915). The APA definition of a rule focuses on the "future effect" of a rule rather than on its generality. See 5 U.S.C. § 551(4) (2011) (defining "rule" as "an agency statement of general or particular applicability and future effect").

${ }^{34}$ Henry J. Friendly, Some Kind of Hearing, 123 U. Pa. L. Rev. 1267 (1975).
} 
not necessarily require a pre-deprivation hearing, ${ }^{35}$ although often it does. Finally, due process requires an impartial decisionmaker, but the Court takes a narrow view of what counts as impartiality; pecuniary interest in the decision at hand is disqualifying, ${ }^{36}$ but there is no general due process prohibition on institutions that combine legislative, executive and adjudicative functions ${ }^{37}$ and thus "judge in their own cause." 38

In an attempt to bring some sort of conceptual order to all this circumstantialism, Mathews announced a marginalist, cost-benefit approach to determining what process is due. Mathews involved payments under Social Security to a putatively disabled beneficiary; it was acknowledged by all concerned that the claimant asserted a protected property entitlement, in the form of "new property" -- an entitlement to public benefits. The contested questions were what process was due in order to protect that claimed entitlement, and when the relevant process was due. In particular, the question was whether the claimant was entitled to an oral evidentiary hearing in the agency before benefits were terminated, or whether the agency could provide only a "paper hearing" before deprivation. Under the agency procedures in place, the claimant could submit written testimony and evidence; an agency official would then consider all the evidence, including medical reports on the claimant's disability, and then decide whether to terminate benefits. Post-termination, the claimant could obtain a full formal hearing on the record, first before an administrative law judge and an agency appeal board, and ultimately before a federal court.

A somewhat similar case decided in 1970 , Goldberg v. Kelly, ${ }^{39}$ had announced a procedural due process entitlement to pre-termination evidentiary hearings when welfare benefits were at issue. The Mathews Court, however, both distinguished Goldberg v. Kelly and moved to clarify the governing framework. The Court announced a simple marginalist calculus of marginal error costs and decision costs -- essentially

\footnotetext{
${ }^{35}$ North American Cold Storage Co. v. Chicago, 211 U.S. 306 (1908).

${ }^{36}$ Tumey v. State of Ohio, 273 U.S. 510 (1927). There is a class of indirect pecuniary interests shared by professional groups that is also disqualifying. See Gibson v. Berryhill, 411 U.S. 564 (1973) (independent optometrists regulating competitor chain-store optometrists). But cf. Friedman v. Rogers, 440 U.S. 1, 1819 (1979).

${ }^{37}$ Withrow v. Larkin, 421 U.S. 35 (1975).

${ }^{38}$ See Adrian Vermeule, Contra "Nemo ludex in Sua Causa": The Limits of Impartiality, 122 Yale L.J. 384, 399 - 400, 404 - 05 (2012).

${ }^{39} 397$ U.S. 254 (1970).
} 
the same one underlying the Hand formula in negligence law, ${ }^{40}$ and the free-speech balancing test of Dennis v. United States. ${ }^{41}$ Under the Mathews calculus,

identification of the specific dictates of due process generally requires consideration of three distinct factors: First, the private interest that will be affected by the official action; second, the risk of an erroneous deprivation of such interest through the procedures used, and the probable value, if any, of additional or substitute procedural safeguards; and finally, the Government's interest, including the function involved and the fiscal and administrative burdens that the additional or substitute procedural requirement would entail. ${ }^{42}$

Under the calculus, there were two key grounds for distinguishing Goldberg v. Kelly. The first was that the private interest affected was weightier in the case of welfare benefits than in the case of disability benefits. Welfare beneficiaries are by definition living on the edge of subsistence, and thus have a powerful interest in full procedure before benefits are terminated. Disability benefits, by contrast, were unrelated to need, and thus beneficiaries could on average more easily tolerate a temporary erroneous deprivation. ${ }^{43}$ The second was the different character of the evidence in disability cases and welfare cases. The former involved medical reports that could be adequately examined in paper hearings, the latter involved facts about the life circumstances of claimants that would more often require personal participation by the claimants. ${ }^{44}$

The Mathews calculus came in for criticism right away. Predictably, some questioned the very notion of "erroneous deprivation" or "accuracy" embodied in the calculus, or questioned its consequentialist character, or at a minimum questioned whether the Court had neglected important consequentialist considerations, such as litigants' appraisal of the legitimacy of the process itself. ${ }^{45}$ I believe most of these

\footnotetext{
${ }^{40}$ See United States v. Carroll Towing Co., 159 F.2d 169, 173 (2d Cir. 1947) (“[T]he owner's duty . . . to provide against resulting injuries is a function of three variables: (1) The probability [of injury]; (2) the gravity of the resulting injury . . ; (3) the burden of adequate precautions. Possibly it serves to bring this notion into relief to state it in algebraic terms: if the probability be called P; the injury, L; and the burden, $B$; liability depends upon whether B is less than $L$ multiplied by $P$ : i.e., whether B < PL.").

${ }^{41} 341$ U.S. 494, 510 (1951) ("In each case (courts) must ask whether the gravity of the 'evil,' discounted by its improbability, justifies such invasion of free speech as is necessary to avoid the danger.") (quoting United States v. Dennis, 183 F.2d 201, 212 (2d Cir. 1950), aff'd, 341 U.S. 494 (1951)) (internal quotation marks omitted).

${ }^{42}$ Mathews v. Eldridge, 424 U.S. 319, 335 (1976).

${ }^{43}$ Id. at $339-43$.

44 Id. at $343-45$.

45 See, e.g., Jerry L. Mashaw, Due Process in the Administrative State (1985); Jerry L. Mashaw, The Supreme Court's Due Process Calculus for Administrative Adjudication in Mathews v. Eldridge: Three Factors in Search of a Theory of Value, 44 U. Chi. L. Rev. 28 (1976); Martin H. Redish \& Lawrence C. Marshall, Adjudicatory Independence and the Values of Procedural Due Process, 95 Yale L.J. 455, 471 75 (1986); Richard B. Saphire, Specifying Due Process Values: Toward a More Responsive Approach to
} 
objections misguided, but will bracket those questions here, excluding them from the topic. My enterprise is not to critique Mathews, but to show that even assuming its validity, it is consistent with a far greater degree of deference to administrative discretion than has been realized to date -- especially once subsequent developments in the law are taken into account.

\section{Legal Norms and Decisionmaking Competence}

A critical analytic distinction for my purposes is the distinction between legal norms, on the one hand, and the allocation of decisionmaking competence ("who decides"), on the other. There is a crucial logical slip in Mathews: to announce a legal norm, even a constitutional norm, is to say nothing at all about which institution is best positioned to implement and apply that norm. Mathews's marginal cost-benefit calculus is not necessarily a rule of decision for judges, although the Mathews Court assumes -for the most part, but not always, as we will see -- that judges should apply it independently. There is no conceptual barrier to saying that the marginalist calculus is the legal norm, but that application of that legal norm should be committed primarily or even wholly to the agency's discretion.

This analytic point is not to be confused with two other, entirely distinct questions: (1) Whether a (total or partial) commitment of decisionmaking competence to agencies in due process cases would comport with the larger fabric and development of public law; (2) Whether it would be a good idea, all things considered. So far I have said nothing on either question; the former is the subject of Part II, the latter the subject of Part III. All I mean to point out here is that one cannot, as a logical matter, derive an answer to the institutional-allocation question from the bare specification of the legal norm. It is perfectly possible to identify a procedural constraint, even a constitutional constraint, yet to entrust application of that constraint to a body other than courts. As we will see, the Mathews Court seemed to conflate these two issues -- until it didn't.

\section{Rules of Decision vs. Standards of Review}

The rule I suggest commits the marginalist Mathews calculus to agencies, subject to arbitrariness review by courts. Under this description, the Mathews calculus is itself the constitutional norm, and the suggestion is that courts should read the Constitution as committing to agencies the primary responsibility for implementing that norm. This description fits with the Court's current understanding of the so-called "political question doctrine" -- the current interpretation of that doctrine being that constitutional norms, rightly understood, might sometimes themselves be entrusted or

Procedural Protection, 127 U. Pa. L. Rev. 111 (1978); William W. Van Alstyne, Cracks in "The New Property": Adjudicative Due Process in the Administrative State, 62 Cornell L. Rev. 445 (1977). 
committed to the decisionmaking competence of non-judicial institutions. ${ }^{46}$ Under this description, the Mathews calculus supplies a rule of decision for the agency.

In contrast to the agency's rule of decision is the court's standard of review. While agencies would have a constitutional obligation to actually apply the Mathews calculus when formulating their procedural rules to implement statutory delegations, the role of the courts will be to ensure that agencies have rationally considered the factors that are relevant under the Mathews calculus and given an adequate explanation for their application of those factors. The court's task is not to decide what the correct application of the factors is, but whether the agency's application was rationally defensible and defended, or instead arbitrary.

This sounds as though I am adapting to constitutional purposes the body of caselaw interpreting the APA's "arbitrary and capricious" test; that caselaw instructs reviewing courts to determine whether agencies have considered the relevant factors and adequately explained their choices. ${ }^{47}$ Actually, the influence goes in the other direction. The idea that judges should review agency decisionmaking under an "arbitrary and capricious" standard of review was originally a due process test, ${ }^{48}$ one that predates the APA. When the APA was drafted, the "arbitrary and capricious" language was lifted from the extant due process caselaw and adapted as a statutory standard of review. Part of my project is to recover a deferential strand of constitutional due process that prevailed in an earlier era. Restoring the "constitution in exile" ${ }^{\text {"9 }}$ may have surprising implications, unanticipated by its proponents. ${ }^{50}$

In another sense, however, the administrative law analogy is exactly correct. Agencies already cite and apply the Mathews factors when designing procedures to

\footnotetext{
${ }^{46}$ See, e.g., Zivotofsky v. Clinton, 132 S. Ct. 1421 (2012).

${ }^{47}$ See 5 U.S.C. $\S 706(2)(A)$ (instructing reviewing courts to set aside agency "action, findings, and conclusions" that are "arbitrary, capricious, [or] an abuse of discretion"); Motor Vehicle Mfrs. Ass'n of U.S., Inc. v. State Farm Mut. Auto. Ins. Co., 463 U.S. 29, 43 (1983) ("The scope of review under the 'arbitrary and capricious' standard is narrow and a court is not to substitute its judgment for that of the agency. Nevertheless, the agency must examine the relevant data and articulate a satisfactory explanation for its action including a 'rational connection between the facts found and the choice made'" (quoting Burlington Truck Lines v. United States, 371 U.S. 156, 168 (1962)).). In the conventional formulation, agencies must also avoid "clear error[s] of judgment." See id. If this is meant to imply a substantive review for clear error, as opposed to procedural review, then it is applied so rarely as to be something of a dead letter. At the Supreme Court level, perhaps the only example is Part V.B of State Farm. See id. at $51-57$.

${ }^{48}$ See, e.g., Pac. States Box \& Basket Co. v. White, 296 U.S. 176, 180 - 82 (1935).

49 See Douglas H. Ginsburg, Delegation Running Riot, 18 Regulation, 83, 84 (1995) (reviewing David Schoenbrod, Power Without Responsibility: How Congress Abuses the People Through Delegation (1993)) (coining the phrase "Constitution-in-exile" to denote certain "banished" doctrines, such as the nondelegation doctrine, and clauses, such as the Takings Clause).

${ }^{50}$ See, e.g., Ginsburg, supra note __; Randy E. Barnett, Restoring the Lost Constitution (2004). To be clear, Barnett doesn't want his Lost Constitution to be lumped in with Ginsburg's Constitution in Exile. See Barnett, supra, at 408 - 12. Yet this looks like the narcissism of small differences; pragmatically speaking, the two have a substantially overlapping agenda and common enemies.
} 
implement statutory delegations. When they do so, they are thinking and talking about the right things. In administrative-law terms, the role of the Mathews calculus is to supply "relevant factors" ${ }^{\text {"1 }}$ that the agency must consider and address, in order to survive arbitrariness review of the agency's procedural choices.

\section{Fit}

So far I have merely stated and clarified the claim. Now let us turn to the considerations that support it, as well as reasonable concerns about it. At the outset, let me be clear about what I take as fixed, and what as variable. I will begin with the dimension of fit, and turn to justification in Part III -- although of course the aim is to achieve reflective equilibrium across the two dimensions, so inevitably I will constantly glance at justification while talking about fit, and vice-versa.

I will take the Mathews calculus as a fixed point, and also assume the validity of broader developments in administrative and constitutional law after Mathews. The paper therefore does not offer a blank-slate theory of procedural due process, but an embedded theory: conditional on accepting the broad outlines of current law, what conception of procedural due process does best on dimensions of both fit and justification? This need not imply, of course, slavish adherence to every decision of every district court. A good embedded theory has some critical bite, tacking back and forth between the legal materials and their best justifications. But the basic structure of the argument will be respectful of extant law. I aim to show that Mathews' core idea, the calculus of procedure, can be respected while allocating front-line responsibility for implementing that calculus to agencies rather than courts, and that such an approach actually makes the most sense of post-Mathews developments in the surrounding legal terrain. Those developments have emphasized the interdependence of procedural choices and policymaking, such that the very reasons that have pushed courts towards deference on legal, ${ }^{52}$ factual ${ }^{53}$ and policy ${ }^{54}$ judgments also support deference on procedural judgments, even when protected entitlements are involved.

Section A explains the confusions and inconsistencies of current procedural due process law. Section B explains the converging strands of post-Mathews caselaw on

\footnotetext{
${ }^{51}$ Citizens to Preserve Overton Park, Inc. v. Volpe, 401 U.S. 402, 416 (1971).

52 See, e.g., City of Arlington v. F.C.C., 133 S. Ct. 1863, 1868 - 75 (2013); Chevron, U.S.A., Inc. v. Natural Res. Def. Council, Inc., 467 U.S. 837, 842 - 45 (1984).

53 See, e.g., Federal Power Comm'n v. Florida Power \& Light Co., 404 U.S. 453 (1972); Universal Camera Corp. v. NLRB, 340 U.S. 474 (1951). See also 2 Richard J. Pierce, Jr., Administrative Law Treatise 768-814 (4th ed. 2002).

54 See, e.g., F.C.C. v. Fox Television Stations, Inc., 556 U.S. 502 (2009); Mobil Oil Exploration \& Producing v. United Distrib. Co., 498 U.S. 211 (1991); PBGC v. LTV Corp., 496 U.S. 633 (1990); Baltimore Gas \& Electric Co. v. Natural Res. Def. Council, Inc., 462 U.S. 87 (1983).
} 
agency procedure, in doctrinal areas abutting due process, that support deference to agency procedural choices.

\section{A. The Due Process Mess}

The problem with procedural due process is that there is not only confusion, but multidimensional confusion. The two main axes are (1) whether courts should independently apply the Mathews calculus; (2) when does the Mathews calculus apply at all. As I will explain, "deference" may or may not be invoked as to either question. The result is an appalling mess, an Augean stable that it would take a Hercules to clean out. But none of our judges is a Hercules.

"Good-Faith Judgments": Deference under Mathews

I will begin with Mathews itself, which was more ambiguous than is usually realized. To be sure, Mathews implicitly assumed, for the most part, that courts should apply the process calculus independently, without deference to the agency's initial determination. But in a cryptic passage towards the end of the opinion, the Court took another tack:

In assessing what process is due in this case, substantial weight must be given to the good-faith judgments of the individuals charged by Congress with the administration of social welfare programs that the procedures they have provided assure fair consideration of the entitlement claims of individuals. . . . This is especially so where, as here, the prescribed procedures not only provide the claimant with an effective process for asserting his claim prior to any administrative action, but also assure a right to an evidentiary hearing, as well as to subsequent judicial review, before the denial of his claim becomes final. ${ }^{55}$

The passage is not discussed in most casebooks, perhaps because it seems out of step with the rest of Mathews. It illustrates that there is no necessary connection between Mathews' due process calculus and the implicit assumption of the commentators that procedural due process must entail the allocation of primary decisional responsibility to courts. In another passage, Mathews gave something of a clue for a rationale that might underpin deference, observing that "procedural due process rules are shaped by the risk of error inherent in the truth-finding process as applied to the generality of cases, not the rare exceptions. " 56 This means that procedural rules must always be designed as a system, in light of the overall goals of the administrative program at issue. In Part III, I will suggest that this implies a leading role for agencies in procedural design, and a subsidiary role for courts.

\footnotetext{
${ }^{55}$ Mathews v. Eldridge, 424 U.S. 319, 349 (1976).

${ }^{56}$ Id. at 344.
} 
So the Mathews opinion took no wholly consistent position on whether courts should independently apply the procedural calculus. Later cases are inconsistent as well. In some cases the Court has described Mathews as an "intrusive" test, and contrasted it with a deferential approach. ${ }^{57}$ Yet a number of cases, both from the Supreme Court and the lower courts, have explicitly or implicitly deferred to agencies in roughly the sort of way I recommend, assessing the rationality of the agency's procedural choices rather than implementing the Mathews test directly.

Supreme Court caselaw. A leading example of the deferential approach is Schweiker v. McClure, ${ }^{58}$ decided in 1982 and written by Justice Powell, the author of Mathews itself. The case involved a network of statutory provisions and administrative regulations providing that certain hearing officers, administering medicare benefits, be appointed by the medicare carriers themselves, rather than being independent administrative-law judges or other government officials. The Court upheld the provisions and regulations, in part on the basis of deference to the procedural judgments of legislature and agency:

[D]ue Process is flexible and calls for such procedural protections as the particular situation demands. We have considered appellees' claims in light of the strong presumption in favor of the validity of congressional action and consistently with this Court's recognition of "congressional solicitude for fair procedure. ..." Appellees simply have not shown that the procedures prescribed by Congress and the Secretary are not fair or that different or additional procedures would reduce the risk of erroneous deprivation of [benefits]. ${ }^{59}$

Notable here are the Court's highly circumstantial description of due process, which naturally emphasizes the factual and policy elements of the enterprise of designing procedural rules, and its attribution to Congress -- and derivatively to the Secretary -- of "solicitude for fair procedure." In Part III, I will amplify on the last point, by way of analogy to John Hart Ely's process-based theory of constitutional judicial review. There is no general reason to think that Congress, or agencies acting under statutory grants, systematically desire to afford as little process as possible to either claimants in benefits cases, or even to regulated entities in other contexts. In benefits cases, the very fact that Congress or the agency has created the benefits program in the first place suggests that it attaches positive weight to beneficiaries' welfare; and many benefitsadministering agencies have voluntarily bound themselves to provide more rulemaking

\footnotetext{
${ }^{57}$ Medina v. California, 505 U.S. 437, 446 (1992), discussed infra, at _.

58456 U.S. 188 (1982).

59 Id. at 200 (citations omitted).
} 
procedure than the APA requires of them. ${ }^{60}$ In regulatory cases, agencies themselves have an interest in providing a generally accurate system of administrative adjudication. Absent some special grounds for suspicion that the agency has crafted a procedural system on distorted or biased grounds, courts have no reason to substitute their judgments for those of the primary decisionmakers.

Schweiker v. McClure is not an outlier. In other cases, the Court has invoked deference in a range of settings. Another leading example involves veterans' benefits. ${ }^{61}$ A statute enacted in the mid-19th century limited to $\$ 10$ the fees that veterans could pay to lawyers for assistance in administrative proceedings to obtain veterans' benefits. ${ }^{62}$ The avowed aim of the statute was paternalistic; Congress feared that veterans would be exploited by unscrupulous lawyers, and the overall benefits system was intended to be a nonadversarial means of transferring resources to veterans. ${ }^{63} \mathrm{~A}$ set of would-be beneficiaries claimed that the limit on lawyer's fees violated due process, because it effectively barred them from retaining private counsel. ${ }^{64}$

The Court rejected the claim, based in large part on two important principles. The first was the premise that "deference to congressional judgment must be afforded even though the claim is that a statute Congress has enacted effects a denial of . . . procedural due process . . .." The second was Mathews' own admonition that procedural due process requires an exercise in system design: "the very nature of the due process inquiry indicates that the fundamental fairness of a particular procedure does not turn on the result obtained in any individual case; rather, 'procedural due process rules are shaped by the risk of error inherent in the truth-finding process as applied to the generality of cases, not the rare exceptions." 66 The second principle supports the first, or so I will suggest when we come to justification.

The residual problem is that these cases do not actually explain when and why deference should or should not be afforded. Nor has the Court explicitly repudiated the pervasive assumption, taught as elementary in the hornbooks, that the Mathews calculus is to be applied independently by the courts. ${ }^{67}$ The unsatisfactory situation is that the nominally prevailing approach is sometimes explicitly contradicted, but never explicitly repudiated.

\footnotetext{
${ }^{60}$ See 5 U.S.C. $\$ 553(a)(2)$ (exempting matters relating to management, personnel property and "benefits" matters from rulemaking requirements); Breyer et al., supra note at 520 .

${ }^{61}$ Walters v. Nat'l Ass'n of Radiation Survivors, 473 U.S. 305 (1985).

62 Id. at 307.

${ }^{63}$ See id. at $309-11,315$.

64 Id. at 308.

65 Id. at 319 - 20 (citing Schweiker, 456 U.S. 188, and Mathews, 424 U.S. at 349).

66 Id. at 321 (quoting Mathews, 424 U.S. at 344).

${ }^{67}$ See sources cited supra note
} 
Lower court caselaw. Lower courts, for their part, sometimes review agencies' procedural choices deferentially, reciting the passage from Mathews about the goodfaith judgments of administrators. A humdrum example is Wilson v. SEC. ${ }^{68}$ Wilson, an investment adviser, was penalized in an SEC proceeding, and complained that the Commission had violated due process by presenting a witness who was examined and cross-examined by telephone. The court, deferring to the Commission's good-faith judgment, reviewed the Commission's procedural determinations under an "arbitrary and capricious" standard and upheld them. The Commission had given valid reasons for using the telephone procedure, rather than face-to-face confrontation, and that was enough. ${ }^{69}$ Similar examples are strewn through the federal reports. ${ }^{70}$

\section{"Far Less Intrusive" - Deference in contrast to Mathews}

There is another line of cases that wields deference in a somewhat different way, albeit with similar practical effects. In this line of cases, deference is taken as a reason not to apply the Mathews framework at all. On this conception, Mathews is taken to be a non-deferential approach, and the key inquiry is into the toggle-switch conditions that determine whether the Mathews framework governs, or instead some alternative deferential framework.

A leading example is Medina v. California, ${ }^{71}$ which determined that the Mathews framework would not govern the allocation of burdens of proof in procedures for determining competency in state criminal courts. ${ }^{72}$ The Court's historical review of the origins of Mathews implied, without quite saying, that Mathews applies only to "administrative law" or "administrative procedures." ${ }^{73}$ In the case of procedures ancillary to the criminal-justice system, however, it was appropriate to apply a historically

${ }^{68} 902$ F.2d 1580 (9th Cir. 1990) (unpublished opinion).

${ }^{69}$ Id.

70 See, e.g., Anderson v. White, 888 F.2d 985, 994 - 95 (3d Cir. 1989) (deferring to agency choice of administrative review procedures in Tax Refund Intercept Program and expressing belief that "the precise choice of hearing procedures is better left to the persons administering TRIP under the flexible balancing test the Supreme Court has prescribed [in Mathews]," id. at 944); Gibbs v. SEC, 25 F.3d 1056 (10th Cir. 1994) (unpublished opinion) (deferring to SEC's good-faith judgment that a hearing and crossexamination by telephone afforded defendant "all the process due," id. at *3); see also, e.g., Old Republic Ins. Co. v. Fed. Crop Ins. Corp., 947 F.2d 269, 282 (7th Cir. 1991) (applying the Mathews test independently but seemingly deferentially, while quoting the "substantial weight to good faith judgments" passage, to uphold the constitutionality of the FCIC's administrative procedures); Turnage $v$. United States, 639 F. Supp. 228 (E.D.N.C. 1986) (same, to uphold the constitutionality of the Food and Nutrition Service's denial of an evidentiary hearing prior to disqualifying a retailer from participating in the federal food stamp program).

${ }^{71} 505$ U.S. 437 (1992).

72 See id. at 442 - 46. Another example is Weiss v. United States, 510 U.S. 163 (1994), which declined to apply the Mathews framework to the military justice system, on the ground that judicial deference is "at its apogee" in that context. Id. at 177 (quoting Rostker v. Goldberg, 453 U.S. 57, 70 (1981)) (internal

quotation mark omitted).

${ }^{73}$ See Medina, 505 U.S. at 444. 
inflected test of fundamental fairness developed in an earlier case, Patterson v. New York. ${ }^{74}$ The key difference between the two tests was deference:

[B]ecause the States have considerable expertise in matters of criminal procedure and the criminal process is grounded in centuries of common-law tradition, it is appropriate to exercise substantial deference to legislative judgments in this area. The analytical approach endorsed in Patterson is thus far less intrusive than that approved in Mathews. ${ }^{75}$

But it is not as though the Court has spoken with one voice, over time, on this issue either. Medina v. California had to confine to their facts -- "without disturbing the[ir] holdings" -- several earlier cases $^{76}$ that had applied the Mathews framework as the governing test, even in proceedings ancillary to the criminal process, such as motions to suppress evidence and capital sentencing. ${ }^{77}$ The core problem, of course, is that the boundary between administrative procedure and criminal procedure is surprisingly illdefined -- an insight of recent scholarship in public law that has cross-fertilized the two subfields. ${ }^{78}$

Inconsistent Law

So there are at least three lines of cases in the picture. One takes Mathews as the touchstone test of due process, at least in the sense that no scope conditions for the application of Mathews are mentioned, and then applies the test independently, without deference to legislative or administrative judgments. A second line applies the Mathews approach with deference built in, but these cases too say nothing to limit the scope of the Mathews approach. The third is explicit about scope conditions, but those conditions are themselves spongy around the edges ("administrative procedure"). Under the third approach, deference is not built into Mathews, but is instead given as a reason not to apply the Mathews test at all.

Analytically, the source of confusion is that the issues are multidimensional. A court must decide both (1) when Mathews applies and (2) whether the Mathews test should be applied according to the court's independent judgment, as a standard of decision, or instead deferentially, as a standard of review. Any particular answer to (1) need not imply any particular answer to (2), and vice-versa. And indeed the three

\footnotetext{
${ }^{74} 432$ U.S. 197 (1977). The actual test under Patterson is whether the state procedure "offends some principle of justice so rooted in the traditions and conscience of our people as to be ranked as fundamental." Id. at 202 (internal quotation mark omitted).

${ }^{75}$ Medina, 505 U.S. at 445 - 46.

76 See Ake v. Oklahoma, 470 U.S. 68 (1985); United States v. Raddatz, 447 U.S. 667 (1980).

77 See Medina, 505 U.S. at 444 (distinguishing Raddatz and Ake).

78 See, e.g., Rachel E. Barkow, Institutional Design and the Policing of Prosecutors: Lessons from Administrative Law, 61 Stan. L. Rev. 869 (2009); Rachel E. Barkow, Administering Crime, 52 UCLA L. Rev. 717 (2005).
} 
approaches we have identified give disparate answers. The first and third approaches agree that Mathews should not be cast as a deferential standard of review. The second and third approaches agree that courts should not necessarily exercise independent judgment about what process is due. The first and second, however, seemingly agree that Mathews always applies. These three propositions (that Mathews always applies, that it should not build in deference, and that courts should not necessarily exercise independent judgment about what process is due) cannot all be true simultaneously, although any two of them can. If the three approaches were persons voting over a multidimensional agenda, a Condorcet paradox of inconsistent aggregation would arise, although each approach is consistent on its own terms.

All this obviously poses, at a minimum, a conventional problem of judicial housekeeping: the doctrine needs to be put into some sort of order. One might even be grandiose and suggest that the current mess is bad enough to warrant concern from the standpoint of the rule of law. More importantly for my purposes, it also underscores that my proposal here is not as radical a departure from the caselaw as might be imagined. At a minimum, the nominal Mathews approach of independent judicial assessment is not to be taken strictly at face value.

The Red Herring of Arnett v. Kennedy

Unfortunately, we are not yet done clarifying the problem and straightening up the mess. The caselaw about the Mathews procedural calculus is entangled with, or obscured by, another defunct line of caselaw. The red herring was dragged across law's path in 1974, two years before Mathews, by Justice Rehnquist, writing a plurality opinion in Arnett v. Kennedy, which said that for due process purposes, substantive entitlements are themselves conditioned on and limited by the statutory procedures provided to enforce them. ${ }^{79}$ The Court has since repudiated Arnett, but it lives on as a bogeyman, an anti-model. Some believe Arnett to be related to the questions examined here, but it actually isn't, or so I will argue. Despite appearances, Arnett has nothing to do with the question whether courts or agencies should have primary responsibility for applying the Mathews calculus. Let me explain.

The claimant in Arnett was a civil servant discharged for cause, as the relevant statute required, but without being afforded a full adversary hearing before termination. The claimant argued that the for-cause limitation created a protected (property) interest, and that the procedures afforded before termination did not provide due process. Justice Rehnquist undertook to kill the burgeoning due process caselaw in its crib, by building the procedures into the definition of the protected entitlement itself:

${ }^{79} 416$ U.S. 134 (1974). 
Here [the claimant] did have a statutory expectancy that he not be removed other than for [cause]. But the very section of the statute which granted him that right, a right which had previously existed only by virtue of administrative regulation, expressly provided also for the procedure by which "cause" was to be determined, and expressly omitted the procedural guarantees which [the claimant] insists are mandated by the Constitution. Only by bifurcating the very sentence of the Act of Congress which conferred upon [the claimant] the right not to be removed save for cause could it be said that he had an expectancy of that substantive right without the procedural limitations which Congress attached to it... Where the grant of a substantive right is inextricably intertwined with the limitations on the procedures which are to be employed in determining that right, a litigant in the position of [the claimant] must take the bitter with the sweet. ${ }^{80}$

Although the logic has seemed compelling to some ${ }^{81}$ to others Rehnquist seemed to offer a trivial non sequitur. So what if the protected interest and the limited procedure are laid out in adjacent statutory clauses? If the Constitution determines procedure, but allows legislatures to determine substance, then one clause may be valid while the other isn't. As Justice Powell put it in a concurrence in Arnett,

[T]he right to procedural due process . . . is conferred, not by legislative grace, but by constitutional guarantee. While the legislature may elect not to confer a property interest in federal employment, it may not constitutionally authorize the deprivation of such an interest, once conferred, without appropriate procedural safeguards. As our cases have consistently recognized, the adequacy of statutory procedures for deprivation of a statutorily created property interest must be analyzed in constitutional terms. ${ }^{82}$

Although a few subsequent cases seemed to adopt the approach of the Arnett plurality, ${ }^{83}$ Powell's view eventually won out. In Cleveland Board of Education v. Loudermill, ${ }^{84}$ the Court emphatically announced that

the Due Process Clause provides that certain substantive rights - life, liberty, and property - cannot be deprived except pursuant to constitutionally adequate procedures. The categories of substance and procedure are distinct. Were the rule otherwise, the Clause would be reduced to a mere tautology. "Property" cannot be defined by the procedures provided for its deprivation any more than

\footnotetext{
${ }^{80}$ Arnett, 416 U.S. at 151 - 54 (emphasis added).

81 See, e.g., Frank H. Easterbrook, Substance and Due Process, 1982 Sup. Ct. Rev. 85 (1983).

82 Arnett, 416 U.S. at 166 - 67 (Powell, J., concurring in part and concurring in the result in part).

83 See, e.g., Ingraham v. Wright, 430 U.S. 651 (1977); Bishop v. Wood, 426 U.S. 341 (1976).

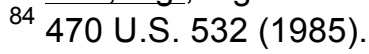


can life or liberty. The right to due process "is conferred, not by legislative grace, but by constitutional guarantee." ${ }^{.85}$

This sequence, although seemingly clarifying, produces its own set of confusions. All that Loudermill settles is that the Constitution, not statute, is the paramount source of law on the question what process is due. As has been true at least since Marbury v. Madison, however, a persistent occupational hazard of (some) lawyers is to skip lightly from the paramount status of the Constitution to the fallacious inference that courts must decide everything for themselves. The "bitter with the sweet" approach of Arnett was a radical attack on due process rights, an attempt to define them away right at the outset. Rejecting that approach, commentators have overcompensated, assuming that anything short of full independent judicial assessment of the Mathews factors would amount to a return to Arnett v. Kennedy. ${ }^{86}$ But this is wrong, analytically wrong.

Not one word in Loudermill denies or even addresses the possibility that the constitutional rule itself might permit or require courts to defer to agencies on the question what process is due. Loudermill speaks rather narrowly to a sources-of-law question, but the deference issue is about two further, interconnected questions: what the constitutional law requires and who decides what the procedural regime will be. A regime in which courts allow agencies to design procedures, subject to arbitrariness review, does not define protected interests out of existence. It recognizes them and then goes on to ask what institutional regime, what allocation of authority to design procedures, will best accommodate that interest as part of a larger system of interests that must be balanced, reconciled, and -- at some resource frontier, assuming agencies do not have infinite time and infinite budgets -- traded off against one another.

Ironically, this approach may actually capture most of what Justice Rehnquist was worried about. Buried at the core of the Arnett plurality was a pragmatic kernel: the plurality referred to the challenged scheme, in which tenured civil servants would receive some, but not full, procedure pre-termination as a "legislative compromise." The underlying concern was to protect an administrative space in which competing aims and values could be traded off against one another. There are two ways of clearing such a space: by a conceptual fusion of entitlements with process that necessarily defines away all constitutional constraint (the Arnett plurality's approach), or instead the creation of a zone of deference in the application of a constitutional standard. The

\footnotetext{
${ }^{85}$ Loudermill, 470 U.S. at 541 (quoting Arnett, 416 U.S. at 167 (Powell, J., concurring in part and concurring in result in part)).

${ }^{86}$ See, e.g., Pierce et al., supra note _, at 244 ("If the judiciary defers to legislative or executive value judgments, as a plurality of the Court argued it should in Arnett, the result would be total emasculation of the Due Process Clause.").

${ }^{87}$ Arnett, 416 U.S. at 154.
} 
rejection of the first approach says nothing at all about the validity of the second. And my suggestion of the second approach does not turn in any way on accepting the first.

\section{B. Converging Precedent}

I turn now to three streams of precedent in adjacent areas of law that fit nicely with a deferential conception of procedural due process. All three are post-Mathews developments. Together with the deferential strands of the due process caselaw itself, they suggest that independent judicial assessment of agency procedures is an increasingly marginal phenomenon -- marginal in both the colloquial and technical senses.

Agency Authority Over Procedure: Vermont Yankee and Perez

The first major development, two years after Mathews, was the Court's emphatic reassertion in Vermont Yankee of the "very basic tenet of administrative law that agencies should be free to fashion their own rules of procedure." ${ }^{88}$ On the basis of that principle, the Court eliminated an entire body of caselaw from the D.C. Circuit that had forced or encouraged agencies to engage in "hybrid rulemaking" -- offering more procedure than organic statutes and the Administrative Procedure Act required for informal rulemaking, although less than would be required under full formal trial-type procedures. $^{89}$

We have to be careful here to distinguish the holding of Vermont Yankee from its reasoning, which swept far more broadly. There are really two Vermont Yankee decisions. One is Vermont Yankee writ small, as a technical legal holding, and one is Vermont Yankee writ large, as a larger set of institutional commitments and principles that may be applied beyond and outside that legal holding. ${ }^{90}$

Strictly speaking, of course, Vermont Yankee writ small merely held that courts have no common-law authority to require agencies to use more or different procedures than those specified in the APA. It did nothing at all to curtail judicial authority over the constitutional law of procedural due process. The Court carefully bracketed "constitutional constraints" as a separate source of procedural requirements ${ }^{91}$-arguably an unnecessary bracketing in any event, as the subject before the Court was procedural requirements in rulemaking, which is subject to minimal constitutional

\footnotetext{
${ }^{88}$ Vermont Yankee Nuclear Power Corp. v. Natural Res. Def. Council, Inc., 435 U.S. 519, 544 (1978).

${ }^{89}$ See generally Antonin Scalia, Vermont Yankee: The APA, the D.C. Circuit, and the Supreme Court, 1978 Sup. Ct. Rev. 345.

90 So too, there is Marbury writ small and writ large, and so on for many other landmark decisions. Indeed this feature of having both writ-small and writ-large versions may be constitutive of landmark status; but this is another topic.

${ }^{91}$ See Vermont Yankee, 435 U.S. at 543.
} 
requirements anyway. ${ }^{92}$ As a technical matter, writ small, Vermont Yankee has nothing to do with constitutional due process.

Yet the institutional rationale of Vermont Yankee -- the writ-large significance of the decision -- is not so easily cabined. The Court's basic insight, and its basic argument for deference, was the interdependence of substance and procedure. In other words, two sets of choices that seem distinct -- (1) the choice of administrative procedures and (2) the choice of rules through substantive administrative lawmaking -are in fact one unitary enterprise. The Court's very first description of the sin of hybrid rulemaking was that it amounts to courts "engrafting their own notions of proper procedures on agencies entrusted with substantive functions"; ${ }^{93}$ and its rationale for the master-principle that agencies, rather than courts, should choose agency procedures was that "administrative agencies and administrators will be familiar with the industries which they regulate and will be in a better position than federal courts or Congress itself to design procedural rules adapted to the peculiarities of the industry and the tasks of the agency involved." ${ }^{14}$

Throughout Vermont Yankee, this point was brigaded with a seemingly distinct point about resource allocation. ${ }^{95}$ Agencies have limited resources, and judicial proceduralization intrudes on the agency's authority to set priorities and allocate limited resources in ways that best ensure the overall achievement of its specified goals. ${ }^{96}$

\footnotetext{
92 See Bi-Metallic Inv. Co. v. State Bd. of Equalization, 239 U.S. 441, 445 (1915). To be sure, Vermont Yankee was extended to informal adjudication in Pension Benefit v. LTV. See Pension Ben. Guar. Corp. v. LTV Corp., 496 U.S. 633, 653 - 55 (1990). In any event I am simplifying a bit here for clarity. In fact the procedures at issue in Vermont Yankee lay at the boundary between rulemaking and adjudication, because the agency was developing general policy assumptions that would be used in subsequent licensing proceedings, which are adjudicative.

${ }^{93}$ Vermont Yankee, 435 U.S. at 525.

94 Id. at 525 (emphasis added) (quoting FCC v. Schreiber, 381 U.S. 279, 290 (1965)) (internal quotation mark omitted). The Court added: "[T] his Court has for more than four decades emphasized that the formulation of procedures was basically to be left within the discretion of the agencies to which Congress had confided the responsibility for substantive judgments. . . Absent compelling constitutional constraints or extremely compelling circumstances, the administrative agencies should be free to fashion their own rules of procedure and to pursue methods of inquiry capable of permitting them to discharge their multitudinous duties." Id. (quoting FCC v. Schreiber, 381 U.S. 279, 290 (1965)) (internal quotation mark omitted).

${ }^{95}$ For an overview of resource allocation in administrative law, see Eric Biber, The Importance of Resource Allocation in Administrative Law, 60 Admin. L. Rev. 1 (2008); for the relationship between resource allocation and the timing of agency action and inaction, see Cass $R$. Sunstein \& Adrian Vermeule, The Law of "Not Now": When Agencies Defer Decisions, 103 Geo. L.J. 157 (2015).

${ }^{96}$ This is not to suggest that resource allocation first appears as a central theme in Vermont Yankee. On the contrary, it is among the most venerable arguments for lodging procedural discretion in agencies. See, e.g., Moog Indus. v. FTC, 355 U.S. 411 (1958) (holding that an agency may proceed against only one out of several similarly situated competitors, because "the Commission alone is empowered to develop that enforcement policy best calculated to achieve the ends contemplated by Congress and to allocate its available funds and personnel in such a way as to execute its policy efficiently and economically," id. at 413).
} 
Indeed, in Heckler v. Chaney, ${ }^{97}$ the Court (once again through Rehnquist) described this as the master rationale of Vermont Yankee. ${ }^{98}$

But resource allocation, on the one hand, and the interdependence of substance and procedure, on the other, are really the same point, just viewed from different angles. The agency enterprise, rightly understood, is optimal policymaking under resource constraints -- an exercise in which the content of rules (whether created through rulemaking or adjudication) and the procedures for arriving at that content are both interdependent variables in the constrained optimization problem. The further point, to be explored in Part III, is that the interdependence of the agency's informational advantage ("expertise") as to the content of rules spills over, as it were, to the procedures for determining what those rules should be.

In emphasizing the interdependence of substance and procedure, I do not wish to be misunderstood as reviving in a different guise the fusion of procedure with substantive entitlements attempted in Arnett v. Kennedy. That approach attempts a complete conceptual fusion of substance and procedure, whereas Vermont Yankee (and Heckler) make a very different type of claim. According to that claim, it is not that procedure and substance are conceptually fused; we can disentangle procedural and substantive decisions at a conceptual level. Rather the point is that one cannot sensibly make choices about one without simultaneously making choices about the other. A producer of wheat must decide, in an interdependent fashion, both what variety to plant (substance) and how and when to plant it (procedure); yet we need not think that the variety and the methods of planting just are the same thing. So too with the producer of administrative policy.

Vermont Yankee is by now an old case, and for many years scholars awaited its second coming. ${ }^{99}$ The wait is over. Just this past Term, in Perez v. Mortgage Bankers Ass'n, ${ }^{100}$ the Court brusquely eliminated a new and different body of D.C. Circuit caselaw on administrative procedure, one that purported to bar agencies from changing

\footnotetext{
97470 U.S. 821 (1985).

${ }^{98}$ See id. at 832 (grounding Vermont Yankee in agency authority to allocate resources through procedural choices).

${ }^{99}$ See, e.g., Paul R. Verkuil, Judicial Review of Informal Rulemaking: Waiting for Vermont Yankee II, 55 Tulane L. Rev. 418 (1981); Richard J. Pierce, Jr., Waiting for Vermont Yankee II, 57 Admin L. Rev. 669 (2005); Paul R. Verkuil, The Wait is Over: Chevron as the Stealth Vermont Yankee II, 75 Geo. Wash. L. Rev. 921 (2007); Jack M. Beermann and Gary Lawson, Reprocessing Vermont Yankee, 75 Geo. Wash. L. Rev. 856 (2007).

100 Perez v. Mortgage Bankers Ass'n, 135 S. Ct. 1199 (2015) (quoting FCC v. Fox Television Stations, Inc., 556 U.S. 502, 513 (2009); Vermont Yankee, 435 U.S. at 549, 544 (internal citations omitted).
} 
"definitive" interpretations except through notice-and-comment procedures. ${ }^{101}$ The Court's admonition was stern:

Time and again, we have reiterated that the APA "sets forth the full extent of judicial authority to review executive agency action for procedural correctness." Beyond the APA's minimum requirements, courts lack authority "to impose upon [an] agency its own notion of which procedures are 'best' or most likely to further some vague, undefined public good." To do otherwise would violate "the very basic tenet of administrative law that agencies should be free to fashion their own rules of procedure." These foundational principles apply with equal force to the APA's procedures for rulemaking...."Agencies are free to grant additional procedural rights in the exercise of their discretion, but reviewing courts are generally not free to impose them if the agencies have not chosen to grant them. ${ }^{102}$

It is striking that although due process is of course an independent source of "judicial authority to review executive agency action for procedural correctness," the sweeping language of Perez omits all mention of due process. There is a logic to the omission: the "foundational principle" Perez underscores is essentially an anti-judicial principle, a constraint on judicial authority to impose additional procedures on executive actors. I will return to this point below.

\section{Chevron and Procedure}

More recent developments have also underscored the interdependence of substance and procedure. A critical question for administrative law involves the allocation of authority between agency and court to interpret procedural provisions in agencies' organic statutes, and related provisions in the APA itself. The Supreme Court has not yet squarely settled the question. But in the lower courts, unless and until overturned, a consensus of the circuits has emerged. The consensus holds that agencies have broad authority to interpret gaps and ambiguities in statutory procedural provisions, including in adjudication, subject only to deferential judicial review. ${ }^{103}$

\footnotetext{
${ }^{101}$ See Alaska Professional Hunters Ass'n v. FAA, 177 F.3d 1030 (D.C. Cir. 1999); Paralyzed Veterans of America v. D.C. Arena L.P., 117 F.3d 579 (D.C. Cir. 1997).

102 Perez, 135 S. Ct. at 1207 (quoting FCC v. Fox Television Stations, Inc., 556 U.S. 502, 513 (2009); Vermont Yankee, 435 U.S. at 549, 544) (internal citations omitted).

${ }^{103}$ See, e.g., Chem. Waste Mgmt., Inc. v. EPA, 873 F.2d 1477 (D.C. Cir. 1989); City of W. Chicago v. U.S. Nuclear Regulatory Comm'n, 701 F.2d 632 (7th Cir. 1983). The Ninth Circuit seems internally conflicted. Compare United Farmworkers of America v. EPA, 592 F.3d 1080 (9th Cir. 2010) (statutory reference to "public hearing" does not trigger formality), with Marathon Oil v. EPA, 564 F.2d 1253 (9th Cir. 1977) (formal proceedings triggered even absent "on the record" language in statute).
} 
The leading case is Dominion Energy Brayton Point, LLC v. Johnson, ${ }^{104}$ in which the First Circuit, reversing its earlier approach, held that a requirement of "public hearing" in the Clean Water Act did not oblige EPA to offer more than a paper hearing, on the basis of written submissions, when deciding upon requests for a variance from permit requirements. Holding that Chevron provided the correct framework, the court described the statutory language as ambiguous. ${ }^{105}$ In conducting the Chevron analysis, the court emphasized that it was asking only whether the agency's procedural choices were "reasonable," and found that EPA had itself reasonably balanced the Mathews factors when deciding whether to afford the regulated party additional procedure. ${ }^{106}$ Here the court did not clearly distinguish the reasonableness of the agency's interpretation, at the second step of Chevron, from the question whether the agency's decisional process was reasonable, or instead "arbitrary and capricious." 107 In this, the court did no worse than the Supreme Court, which has frequently and sometimes deliberately conflated the two inquiries as well. ${ }^{108}$

Dominion Energy's deferential approach to the interpretation of statutory procedural clauses supplies an analogy, an exportable model, for the approach to procedural due process that I urge. Agencies' procedural choices should be reviewed to determine whether agencies have considered the Mathews factors and offered minimally acceptable reasons for their optimizing interdependent choices -- no more. I will take up the justifications for this approach in Part III. For now, we need know only that the near-universal consensus among the courts of appeal is now that Chevron deference applies to agencies' interpretation of statutory procedures -- a position that in

\footnotetext{
104443 F.3d 12 (1st Cir. 2006).

${ }^{105}$ Dominion Energy, 443 F.3d at $17-18$.

106 Id. at 18:
}

"In this instance, the administrative interpretation took into account the relevant universe of factors. See 65 Fed. Reg. at 30,898-30,900 (considering '(1) [t]he private interests at stake, (2) the risk of erroneous decision-making, and (3) the nature of the government interest,' and concluding that its new regulation was a reasonable interpretation of the CWA); see also Chem. Waste Mgmt., 873 F.2d at 1483 (concluding that the EPA's choice of informal adjudicatory procedures under RCRA was reasonable). The agency's conclusion that evidentiary hearings are unnecessary and that Congress, in using the phrase 'opportunity for public hearing,' did not mean to mandate evidentiary hearings seems reasonable ...."

To be clear, Dominion Energy reviewed EPA's Mathews analysis only in the course of determining whether the agency's statutory position was reasonable, not as part of a direct due process challenge, for the simple reason that no such challenge was brought or considered. The leading cases in other circuits, however, have clearly considered both statutory and due process arguments in turn. See Chemical Waste Management, 873 F.2d at 1480 - 85; City of West Chicago, 701 F.2d at $642-47$.

${ }^{107} 5$ U.S.C. $\S 706(2)(A)(2012)$.

108 See, e.g., Judulang v. Holder, 132 S. Ct. 476,483 n.7 (2011). For an attempt to straighten out the categories, and sharpen the distinction between the Chevron inquiry and arbitrariness review, see Matthew C. Stephenson \& Adrian Vermeule, Chevron Has Only One Step, 95 Va. L. Rev. 597, 602 - 06 (2009). 
effect places front-line authority for applying the Mathews calculus in agencies rather than courts, as occurred in Dominion Energy itself.

\section{Chevron and "Jurisdiction"}

The last converging strand involves a legal rule that is (now) firmly settled, eminently logical, and yet odious to the traditional legal mind: agencies receive judicial deference on the statutory boundaries of their own authority -- what traditional lawyers call their "jurisdiction." 109 The relevance of this is indirect, but important nonetheless. Stock arguments against deference to agencies' procedural choices invoke the risk of agency self-dealing, the risk that a legal rule putting agencies in charge (within rational limits) of their own procedures would in effect make agencies "judges in their own cause." Traditional legalists made exactly the same self-dealing argument to show that agencies could not enjoy deference on the limits of their own jurisdiction. The Court, however, rejected the argument on grounds that apply to the procedural setting as well. Law itself has partly abnegated its authority over both agency jurisdiction and agency procedure, for similar reasons.

The starting point must be Crowell v. Benson, ${ }^{110}$ the great 1932 decision in which Chief Justice Hughes attempted to establish an equilibrium compromise between the administrative state and the traditionalist claims of law and judicial power. The main outlines of the compromise were that when agencies adjudicated cases of "private right" as between private parties, courts would decide all legal questions de novo, whereas agencies would enjoy deference on questions of fact, subject to substantial-evidence review. ${ }^{111}$ There were two major exceptions to deference, however, for "jurisdictional facts" and "constitutional facts." 112

Without delving into the arcana surrounding these categories, the important thing is Hughes's admonition that unless courts review de novo the facts on which agency jurisdiction depends, the result "would be to sap the judicial power as it exists under the federal Constitution, and to establish a government of a bureaucratic character alien to our system." 113 To be sure, the category of "jurisdictional fact" rather quickly faded into the twilight reserved for doctrines that are only half-alive. But a related notion floated around the margins of Chevron doctrine after 1984 -- the notion that there was some sort of exception to Chevron for "jurisdictional questions." 114 Along Hughes's lines, the traditional legal mind has always felt -- although the feeling is protean and assumes

\footnotetext{
${ }^{109}$ See City of Arlington v. FCC, 133 S. Ct. 1863 (2013).

110285 U.S. 22 (1932).

${ }^{111}$ See id. at $51-54$.

112 See id. at $54-60$.

113 Id. at 57.

114 See Mississippi Power \& Light Co. v. Mississippi ex rel. Moore, 487 U.S. 354, 386 - 87 (1988)

(Brennan, J., dissenting).
} 
ever-shifting doctrinal forms -- that courts must determine for themselves de novo what the boundaries of agency jurisdiction are, including the facts that determine those boundaries.

In City of Arlington v. FCC, decided in 2013, the Court swept away the whole idea that agency "jurisdiction" is an exceptional category. In what is perhaps the most relentlessly logical majority opinion in the U.S. Reports, Justice Scalia even denied that any identifiable category of "jurisdictional" questions exists or ever existed. Under any organic statute, the logic runs, there are $\mathrm{N}$ statutory prerequisites to the agency's exercise of coercive legal authority over regulated parties. Absent any one of these statutory prerequisites, the agency lacks legal power to proceed. There is no basis for singling out some particular subset of those prerequisites and labeling them "jurisdictional." Chevron deference must extend to all the prerequisites, or to none. The only question is whether the agency's assertion of statutory authority is or is not "reasonable."115

For my purposes, however, the validity of City of Arlington's main logical argument is not essential. The more significant idea in the opinion is the Court's rejoinder to the ancient, nearly reflexive traditionalist concern about administrative selfdealing: the idea that deference to agencies on the scope of their statutory "jurisdiction" would make agencies "judges in their own cause" or "put the fox in charge of the henhouse." In City of Arlington, the Court rejected the concern over agency self-dealing by reasserting judicial authority to police clear statutory violations by agencies: "The foxin-the-henhouse syndrome is to be avoided not by establishing an arbitrary and undefinable category of agency decisionmaking that is accorded no deference, but by taking seriously, and applying rigorously, in all cases, statutory limits on agencies' authority. Where Congress has established a clear line, the agency cannot go beyond it; and where Congress has established an ambiguous line, the agency can go no further than the ambiguity will fairly allow."116

The same applies in parallel, or so I will argue in Part III, to agency choice of procedures. Courts should police agencies to ensure that (1) clear procedural provisions in statutes are honored, while agencies have discretion to interpret ambiguities (as in Dominion Energy); (2) agencies have remained within reasonable bounds in their application of Mathews' marginalist analysis of procedure. The former constraint does for agency choice of procedures, under Mathews and the constitutional guarantee of procedural due process, exactly what City of Arlington does for agency

${ }^{115}$ See City of Arlington v. FCC, 133 S. Ct. 1863, 1868 - 74 (2013). Incidentally, that description of the Chevron inquiry is strong precedent for the view urged in Matthew C. Stephenson \& Adrian Vermeule, Chevron Has Only One Step, 95 Va. L. Rev. 597 (2009).

${ }^{116}$ City of Arlington, 133 S. Ct. at 1874. 
assertions of statutory authority, while the latter constraint adds a layer of judicial review that goes beyond what is available in purely statutory cases about agency procedure.

Here is the larger picture. We have these three adjacent areas of precedent, none of which directly involves procedural due process (although Dominion Energy sits right on the line). In all three areas, after Mathews, the underlying rationales and principles embody a judicial willingness to carve out space for greater agency discretion over procedural choices. It is time to circle back to the main issue, and apply those principles directly to procedural due process itself.

\section{Justification}

Let us turn from fit to justification, bearing in mind that we will always be tacking back and forth between the two. The converging strands of caselaw after Mathews are not unreasoned. They rest on a set of institutional principles -- principles that, rightly understood, limit the reach of "Law's Empire."

Procedure, Substance, and Expertise

The leading critique of Dominion Energy correctly remarks that "issues involving procedural provisions are distinct from substantive issues." ${ }^{117}$ Again, however, although the two are indeed conceptually and analytically distinct, the problem is that they are pragmatically interdependent, in the larger institutional system of agency decisionmaking. In Dominion Energy itself, it is not clear how the most well-motivated agency could think coherently about the substantive questions in some given array of regulatory variance decisions without also, and simultaneously, thinking about how much time and resources to invest in determining whether to grant a variance in particular cases. The decision over how much procedure to afford, with some resulting costs of decisionmaking and of error, just is a decision about the allocation of limited agency resources -- a decision about optimization under constraints.

For reasons of this sort, Louis Jaffe, in the quoted epigraph, observed that expertise as to substance is impossible to cabin and separate cleanly from procedural discretion. Substance spills over into procedure, obliterating the traditional legalism that while agencies may understand the substantive problems involved, courts are experts at procedure. The two cannot be separated, pragmatically speaking, because the design of a procedural system for agency decisionmaking will itself determine, at least in part, whether, how and when the agency will achieve its substantive goals, and what

\footnotetext{
117 Melissa M. Berry, Beyond Chevron's Domain: Agency Interpretations of Statutory Procedural Provisions, 30 Seattle U. L. Rev. 541, 589 (2007). Berry's important critique argues that "agency expertise is a weak rationale for deference to agency interpretations of procedural provisions" because substantive and procedural requirements are distinguishable and "courts have more expertise in interpreting procedural requirements." Id.
} 
tradeoffs agencies will make when multiple substantive goals interact. In a world of limited resources, agencies must allocate resources. The same point in effect underlies both Vermont Yankee and the post-Chevron cases on the interpretation of procedural provisions in organic statutes. ${ }^{118}$ Although those cases nominally involve subconstitutional questions, and are thus nominally consistent with fully independent judicial application of Mathews, their underlying premises are not so easily confined.

Part of the problem here is that the traditional legalism elides the distinction between systemic and case-specific thinking, and the problems of resource allocation that inevitably arise when agencies must think in aggregate long-run terms. In any given case, it is true, ex post, from the standpoint of a reviewing institution like a court, that we can imagine arriving at the given substantive decision by different procedures, or arriving at a different substantive decision with the same procedures. But that casespecific and ex post standpoint is not the agency's own standpoint. The agency's problem is always ex ante and aggregated; its problem is to design and operate a procedural system over an array of cases, deciding at several margins simultaneously where and how to invest its limited resources in deciding what policies and legal rules to adopt. That sort of optimizing cannot be substance-independent; the agency will have to decide which sorts of errors are more costly, how many resources in can invest in which sorts of decisionmaking, and which sorts of proceedings or cases will yield the greatest return-on-investment for its policy goals.

Systemic Procedure and the Marginal Benefits of Judicial Review

Thus Mathews itself correctly emphasizes, ${ }^{119}$ as do later cases, ${ }^{120}$ that the correct perspective in matters of due process is systemic. Every procedural decision that agencies make implicitly amounts to, and presupposes, a view about the design and operation of the overall system. But Mathews did not fully appreciate the implications of its own systemic logic. Despite the Court's aside that the "good-faith

\footnotetext{
${ }^{118}$ See, e.g., Vermont Yankee Nuclear Power Corp. v. Natural Res. Def. Council, 435 U.S. 519, 525, 543 (1978) ("[T]he formulation of procedures [is] basically to be left within the discretion of the agencies to which Congress had confided the responsibility for substantive judgments. . . . Absent compelling constitutional constraints or extremely compelling circumstances, the administrative agencies should be free to fashion their own rules of procedure and to pursue methods of inquiry capable of permitting them to discharge their multitudinous duties." (quoting FCC v. Schreiber, 381 U.S. 279, 290 (1965)) (internal quotation mark omitted)).

${ }^{119}$ Mathews v. Eldridge, 424 U.S. 319, 344 (1976) (“[P]rocedural due process rules are shaped by the risk of error inherent in the truthfinding process as applied to the generality of cases, not the rare exceptions.").

${ }^{120}$ See, e.g., Walters v. Nat'l Ass'n of Radiation Survivors, 473 U.S. 305, 321 (1985) ("In applying [the Mathews] test we must keep in mind, in addition to the deference owed to Congress, the fact that the very nature of the due process inquiry indicates that the fundamental fairness of a particular procedure does not turn on the result obtained in any individual case; rather, 'procedural due process rules are shaped by the risk of error inherent in the truth-finding process as applied to the generality of cases, not the rare exceptions."' (quoting Mathews, 424 U.S. at 344)).
} 
judgments"121 of administrators must be respected, the pervasive assumption of the opinion was that courts should apply the calculus independently. If procedural decisions are not only pragmatically intertwined with substantive ones, but also inevitably and necessarily aggregative and systemic, then the right question is whether courts or agencies are better positioned to design the agency's overall procedural system. More precisely still, the question is marginalist: given that agencies will inevitably be forced to take some view or other about the design of procedural systems, what marginal contribution do the judges make when reviewing those decisions?

It has seemed obvious to increasing numbers of judges themselves -- the judges who have fashioned the post-Mathews caselaw on agency procedural discretion, over the past two generations -- that agencies are better positioned to design procedural systems. Federal judges get snapshots of agency procedure in particular cases; the limited institutional memory of a federal circuit does not provide the overall perspective that agency officials enjoy. The federal judicial system is not set up, not equipped, to engage in a sustained course of synoptic institutional engineering. ${ }^{122}$ The limits of the generalist, case-specific and episodic perspective of the federal judicial system are exacerbated by a world in which the underlying problems become increasingly complex; the design of procedures for nuclear plant operator licenses is a very different problem than, say, the design of procedures for carriage licenses.

This is not to say that the judicial system is helpless or that it makes no marginal contribution at all. Shortly I will suggest that the judges should retain the sort of role they play in other areas of administrative law, by examining the reasons agencies give for their procedural choices, and thereby providing agencies with an ex ante incentive to proceed on the basis of defensible reasons. But I do mean to say that judges should recognize -- and increasingly have recognized -- the possibility that their limited information, episodic perspective, and time constraints together imply that the marginal benefits of judicial intervention in procedural design may be low or even negative, as the intensity of intervention increases.

\section{A Process Failure Approach}

Another angle of vision comes most directly from constitutional theory rather than administrative law. The process-failure literature stemming from John Hart Ely proposes a judicial role limited to reinforcing democratic representation, rather than the substitution of judicial value judgments for those of the political branches. ${ }^{123}$ The Elyian judge asks, in brief, whether there has been some political self-dealing that chokes off

\footnotetext{
${ }^{121}$ Mathews, 424 U.S. at 349.

122 Donald L. Horowitz, The Courts and Social Policy (1977).

${ }^{123}$ See John Hart Ely, Democracy and Distrust (1980).
} 
the channels of political change, and whether some sort of majoritarian bias is in evidence. ${ }^{124}$ Absent either condition, the Elyian judge will stay her hand.

Part of Ely's representation-reinforcing approach happened to involve a somewhat reinvigorated "nondelegation doctrine,"125 with which I disagree. ${ }^{126}$ (Indeed I disagree in part because of Ely's own premises, and think that he misunderstood the implications of his own views when it comes to nondelegation; but that is another story). But we may bracket such questions here in any event. If there is a nondelegation problem, there is, and if there isn't, there isn't; but any such problem is separate from and tangential to the due process problem. No one has ever seriously claimed that there are nondelegation problems in the leading due process cases, which -- because they require a cabined, well-defined "protected entitlement" to exist in the first place -tend to arise under statutes that are if anything so thickly-specified that they constrain administrative discretion, rather than providing agencies with a blank check.

For my purposes, all I want to suggest is an Elyian perspective on the procedural due process problem. On this perspective, rather than plunging into procedural design themselves, courts should stop, look, listen, and then ask a logically antecedent question: is there any reason to think that the relevant agency will have systematically skewed incentives or make systematically distorted judgments when applying the Mathews calculus, such that the agency will systematically over-weight or under-weight particular factors? If there is no reason to think that the agency has systematically distorted incentives or is prone to systematic distortions of judgment, then there is no reason for judges to displace agency choices about the marginal costs and benefits of additional (or different) procedure in the execution of the agency's program. Agencies may of course make random errors, but so too may judges -- especially generalist judges deciding on the value of procedures under programs they only dimly understand.

Agency Motivations and Judgments: Some Mistakes

At this point one tends to encounter a number of sweeping generalities about agency motivations and judgments:

(1) Agencies want to offer as little procedure as possible, perhaps because they are "mission-oriented."

(2) Agencies are "political," so procedural judgments are politicized rather than "impartial."

(3) Courts are experts in "procedure," agencies are not.

\footnotetext{
124 Id. at $105-79$.

125 See id. at $131-34$.

126 See Eric A. Posner \& Adrian Vermeule, Interring the Nondelegation Doctrine, 69 U. Chi. L. Rev. 1721, 1748 (2002).
} 
(4) In a variant of (3), lawyers are experts in procedure, agency technocrats are not. Of course it is possible to mix and match these generalizations -- combining (1) with (2), or (2) with (3), or smushing all of them together.

The main thing to say about such judgments is "not really." Some are demonstrably false, some merely overblown. Obviously there are oceans of literature on the motivations and judgments of both agencies and courts, in both legal theory and political science. It's hard to generalize, which is my point; because it is hard to generalize, courts should not use an approach that implicitly rests on crude stereotypes or on systematic distrust of agencies' procedural choices.

Let me offer a few comments on each of these flawed generalizations in turn:

(1) It is not the case that agencies want to offer as little procedure as possible. ${ }^{127}$ In rulemaking, where Vermont Yankee first squashed judicial requirements of "hybrid" procedure, agencies frequently offer more procedure than the notice-and-comment requirements of APA $\S 553$ demand, even as judicially interpreted. ${ }^{128}$ Agencies may offer cross-examination of staff, oral presentations, or other components of formal trialtype hearings. In adjudication the same is true, ${ }^{129}$ even after the Vermont Yankee rule was explicitly extended to informal adjudication in $1990 .{ }^{130}$ Even when statutes do not require a formal "hearing on the record" sufficient to trigger the APA procedures for trialtype adjudication, the bare-bones procedure for informal adjudication in APA $\S 555$ is often voluntarily supplemented by the agencies themselves. ${ }^{131}$

So it is a misconception that agencies will never offer more procedure than they are legally required to offer. There is any number of reasons why agencies often go beyond their legal obligations; again, the point is that it is very hard to generalize. Sometimes they do so to appease constituencies, stakeholders, or regulated parties who wish to be heard (or who wish to show to their own constituents and stakeholders that they have been heard); sometimes they do so to make a full record for judicial review; sometimes -- more frequently than cynics believe -- agencies may simply think, on Mathews-type grounds, that the issue at hand warrants more process than the legally mandated minimum. But one of the major reasons agencies go beyond the legal minimum is that, precisely when and to the extent that agencies are mission-oriented, they will have an interest in accuracy, and will sometimes provide extra procedure in order to ensure accuracy (at least in an aggregate sense). Accuracy often appears on

\footnotetext{
${ }^{127}$ See Elizabeth Magill, Agency Self-Regulation, 77 Geo. Wash. L. Rev. 859, 868 (2009).

128 See Pierce et al., supra note _, at 361.

129 See id. at 367; see also Paul Verkuil, A Study of Informal Adjudication Procedures, 43 U. Chi. L. Rev. 739 (1976).

${ }^{130}$ See Pension Ben. Guar. Corp. v. LTV Corp., 496 U.S. 633, 653 - 55 (1990).

131 See Richard J. Pierce, Jr., 2 Administrative Law Treatise section 9.1 ("Agencies almost invariably provide procedures greater than those required by the APA when they engage in informal adjudication.")
} 
both sides of the ledger, both the side of the agency and that of the regulated entity; promoting accuracy is sometimes a common interest. ${ }^{132}$

The SEC, for example, has little interest in inaccurate administrative adjudication of civil penalties. ${ }^{133}$ Errors in its own internal adjudication are costly, in part because erroneous decisions are more likely to be challenged in court on evidentiary grounds, in part because erroneous imposition of penalties actually dilutes deterrence. If penalties were imposed randomly, there would be no deterrence of regulated parties, and the agency's mission of efficient regulation would actually suffer; hence to some degree, at least, the agency and regulated parties have a joint interest in accuracy. Agencies will, of course, never be willing to invest as much in any given case as regulated parties might like, yet that does not or at least need not show any distortion of incentives or judgments on the agencies' part. What it shows is that agencies have to balance more considerations than do single-minded parties. Judges sometimes overlook this by focusing on the particulars of the case at hand; they observe, correctly, that some extra increment of procedure would have increased accuracy in that case, forgetting that under resource constraints, more procedure here means less procedure there.

(2) Of course there is a sense in which all agencies are "political." There is also a sense in which all courts are "political" -- as an ever-growing pile of evidence on attitudinal and strategic voting demonstrates. ${ }^{134}$ There is another sense, however, in which neither agencies nor courts are "political," not pejoratively anyway. The universal testimony of both agency officials and judges is that cases are rarely if ever decided, nor rules made, on grounds that are political in the core sense of "telephone justice" -that some powerful person $\mathrm{X}$ favors the interests of person $\mathrm{Y}$ for corrupt or ideological reasons. On the other hand, the universal testimony of both agency officials and judges is that agencies do act "politically" in the quite appropriate sense that agencies adopt the value premises held by democratically-elected officials who are influential with the

${ }^{132}$ Cf. Pierce et al., supra note _, at 236 - 37 (“An agency often perceives its dominant goal as maximizing the accuracy and fairness of its decisionmaking process consistent with the resources available to it. In such circumstances, the agency may voluntarily choose decisionmaking procedures more demanding than those imposed by Congress or the courts.").

${ }^{133}$ See, e.g., statement of Andrew Cerseney, SEC Director of Enforcement, Nov. 25, 2014 (explaining that the SEC is vigilant to reverse ALJ decisions that erroneously rule in the agency's favor).

${ }^{134}$ See, e.g., Frank B. Cross \& Emerson H. Tiller, Judicial Partisanship and Obedience to Legal Doctrine: Whistleblowing on the Federal Courts of Appeals, 107 Yale L.J. 2155, 2175 (1998); Thomas J. Miles \&

Cass R. Sunstein, The Real World of Arbitrariness Review, 75 U. Chi. L. Rev. 761 (2008); Thomas J. Miles \& Cass R. Sunstein, The New Legal Realism, 75 U. Chi. L. Rev. 831 (2008); Thomas J. Miles \& Cass R. Sunstein, Do Judges Make Regulatory Policy? An Empirical Investigation of Chevron, 73 U. Chi. L. Rev. 823 (2006); Richard J. Pierce, Jr., Two Problems in Administrative Law: Political Polarity on the District of Columbia Circuit and Judicial Deterrence of Agency Rulemaking, 1988 Duke L.J. 300 (1988); Cass R. Sunstein, David Schkade, \& Lisa Michelle Ellman, Ideological Voting on Federal Courts of Appeals: A Preliminary Investigation, 90 Va. L. Rev. 301 (2004). But see Richard J. Pierce, Jr. \& Joshua Weiss, An Empirical Study of Judicial Review of Agency Interpretations of Agency Rules, 63 Admin. L. Rev. 515, 521 - 23 (2011); David Zaring, Reasonable Agencies, 96 Va. L. Rev. 135 (2010). 
agency, as overseers, stakeholders, appointers of agency heads, or hierarchical superiors. Such premises must come from somewhere, and if they do not come from agencies (derivatively), they will come from the judges themselves, which will be no less "political."

All that said, my main point, here and throughout, is that generalizations about agencies are treacherous in the extreme, and that legal rules must always take account one way or another of agency heterogeneity. The idea that agencies are "political" is a particularly meaningless generalization. It elides the differences between independent agencies and executive agencies, which may or may not both be "political," but are at least political in different ways, with respect to different constituencies; ${ }^{135}$ between or among agencies whose members are chosen according to strict statutory requirements of partisan balance, multimember agencies without partisan balance requirements, and single-head agencies; and on and on. As I will discuss shortly, rationality review of agencies' procedural choices is the most flexible and natural way to flush out "political" motivations, somehow defined, if those are taken to be something that need to be flushed out. Whether they should be so taken is a separate question. There is a live debate in administrative law about whether rationality review does or should allow agencies to make choices on "political" grounds, with varying definitions of "political" flying about. ${ }^{136}$ I need not engage that debate, because it cuts across the category of procedural choices that I examine here.

(3)-(4) The traditional lawyer's conceit about procedure -- that the legal profession has some sort of peculiar expertise in the design of procedural rules -- is mystifying, in several senses. First, the basis for the conceit is mystifying; every profession designs procedures for the conduct of its business, economists and doctors and corporate managers and public administrators no less than lawyers. Indeed the drafters of the APA themselves recognized the existence of a distinctive category of "business procedures" that agencies might adopt in certain circumstances. ${ }^{137}$ Second, the relevance of the conceit is mystifying. Lawyers work within agencies as well as on the bench, or at the bar. If lawyers are experts in procedural design, why should the judgments of one set of lawyers, the ones to be found in courts, trump the earlier

\footnotetext{
135 See F.C.C. v. Fox Television Stations, Inc., 556 U.S. 502, 523 (2009) (“The independent agencies are sheltered not from politics but from the President, and it has often been observed that their freedom from presidential oversight (and protection) has simply been replaced by increased subservience to congressional direction.").

${ }^{136}$ See, e.g., Nina A. Mendelson, Disclosing "Political" Oversight of Agency Decision Making, 108 Mich. L. Rev. 1127 (2010); Kathryn A. Watts, Proposing a Place for Politics in Arbitrary and Capricious Review, 119 Yale L.J. 2 (2009).

${ }^{137}$ See Attorney General's Manual on the Administrative Procedure Act (1947), at 40 (describing "governmental functions, such as the administration of loan programs, which traditionally have never been regarded as adjudicative in nature and as a rule have never been exercised through other than business procedures").
} 
judgments of another set, the ones who designed the agency procedures in the first place? And, finally, the effects of the conceit may well be mystifying in a Benthamite sense, insofar as the conceit deters law's subjects from questioning whether judges are well-positioned to design agency procedures, or even to make a marginal contribution to the enterprise of design.

\section{Flushing Out Agency Motivations and Judgments}

None of this is to say that agencies will never act from bad motivations or from distorted judgments. I certainly do not want to overclaim, or to be understood as suggesting that the crude generalizations I have criticized should be replaced by crude generalizations in the opposite direction. What I do mean to say is that no large generalizations are possible. Precisely because that is true, procedural due process should rest on a posture of judicial agnosticism about agency motivations, accompanied by the same presumption of regularity that is generally taken as the baseline for evaluating administrative action. That presumption may be rebutted by a showing, in the circumstances, that agencies have not offered rational grounds for their procedural choices.

Put differently, I suggest that even in the domain of procedural due process, courts should use one of law's standard methods for flushing out undesirable agency motivations or distorted agency judgments: requiring agencies to provide valid reasons for their choices. ${ }^{138}$ Agencies acting on the basis of undesirable motives or distorted judgments will, all else equal, find it more costly to provide reasons that plausibly justify their choices, and the worse their motives or judgments, the costlier it will be. That approach allows the problem of agency motivations and judgments to be approached in a standard-like way rather than a rule-like way, without sweeping generalizations, but with sensitivity to the particular statutes, programs and circumstances at issue.

When courts apply Mathews independently, however, not reviewing the agency's choices but making the choices themselves, they are in effect making extreme assumptions about agency motivations, or judgments, or both. They are assuming, quite invisibly, that agencies are systematically not to be trusted, and that courts must step in to decide on sensible agency procedures de novo. The result is a kind of irrebuttable presumption of distrust. An approach to Mathews that makes it a standard

\footnotetext{
${ }^{138}$ More controversially, I believe that among valid agency reasons are second-order reasons that justify making decisions that are "rationally arbitrary" in a first-order sense, especially under conditions of uncertainty. See Adrian Vermeule, Rationally Arbitrary Decisions (in Administrative Law), $44 \mathrm{~J}$. Legal Stud. 7 (forthcoming 2015). In this setting, agencies may often face genuine uncertainty about the marginal costs and benefits of procedural choices under the Mathews inquiry; they may nonetheless have valid reasons to truncate the procedural inquiry and settle on procedures that cannot be fully justified in a first-order sense. Let me be clear, however, that my main thesis in text does not stand or fall by this extra twist. One may reject the validity of rationally arbitrary decisions, yet subscribe to the deferential approach to procedural due process that I advocate.
} 
of review for courts and a rule of decision for agencies, rather than a rule of decision for courts, would avoid making such sweeping assumptions. It would embody a more nuanced rebuttable presumption of agency regularity, assuming that agencies' front-line experience and superior information about the substance of relevant programs counts for something, and that courts may use ordinary review of agency reason-giving to flush out marginal cases of bad agency motivation or distorted judgments.

The Fox and the Henhouse

Finally, let me return to the question of agency self-dealing, a concern often invoked with the aid of the maxim nemo iudex in sua causa -- "no man should be judge in his own cause." This is a standard reflex for lawyers who critique judicial deference to agencies' procedural choices; such deference makes the agencies judges in their own causes, doesn't it? For reasons both general and particular, however, I think this reflex ought to be resisted if at all possible.

The general reason is that even the most casual overview of constitutional law shows that there just is no general principle against making institutions judges in their own cause; state and national constitutions, including our own, frequently make institutions the final arbiters of their own composition, compensation, or power. ${ }^{139}$ Legislators determine the boundaries and composition of their own constituencies, decide who counts as a validly seated member of the legislature, and set their own salaries. The President may pardon friends, family and subordinates, and quite arguably even himself, while the Vice President may quite arguably preside at his own impeachment. Judges determine the constitutionality of provisions that set their own salary, sometimes by hearing class action suits composed of all judges -- thus quite literally sitting as judges in their own cause. (All this occurs under cover of a judiciallycreated doctrine, the "rule of necessity." Why exactly it is necessary that judges be able to decide such matters is not altogether clear). The final culprit is judicial review itself, which as Jeremy Waldron points out in effect makes the Supreme Court the final legal arbiter of its own constitutional power. ${ }^{140}$

\footnotetext{
${ }^{139}$ See generally Vermeule, Contra Nemo ludex in Sua Causa, supra note

140 Jeremy Waldron, The Core of the Case Against Judicial Review, 115 Yale L.J. 1346, 1400 (2006):
}

\begin{abstract}
"Those who invoke the maxim nemo iudex in sua causa in this context say that it requires that a final decision about rights should not be left in the hands of the people. Rather, it should be passed on to an independent and impartial institution such as a court. It is hard to see the force of this argument. Almost any conceivable decision-rule will eventually involve someone deciding in his own case. Unless we envisage a literally endless chain of appeals, there will always be some person or institution whose decision is final. And of that person or institution, we can always say that because it has the last word, its members are ipso facto ruling on the acceptability of their own view."
\end{abstract}


So constitutional law not infrequently makes officers or institutions the judges of their own compliance with the Constitution itself. The Court has recognized, in other words, that it is perfectly intelligible to say both that (1) the Constitution creates a legal norm that constrains some institutional actor; and (2) that the Constitution commits to that very actor the determination whether the norm has been complied with. Perhaps the most dramatic example involves the procedural rules to be used in a federal impeachment trial in the Senate, where -- the Court has said -- the Senate itself enjoys unreviewable authority to determine whether the constitutional rules have been followed. ${ }^{141}$ The approach to procedural due process that I propose does not go so far as that; it sees the constitutional rule as committing the procedural calculus to executive discretion, but only subject to judicial review for arbitrariness.

So much for the general background of constitutional law, which simply cannot be successfully understood through the lens of the nemo iudex maxim. The particular reason involves administrative agencies and their decisions, both procedural and substantive, in adjudication. The pure baseline position -- the imagined world of the nemo iudex maxim, a world that may or may not have ever existed -- cannot be invoked as a guiding principle with respect to particular issues in administrative law, because our whole administrative law emphatically rejects that baseline position. The architects of the administrative state, acting with eyes open, severely compromised the nemo iudex principle by combining in the hands of agencies the classical functions of lawmaking, law-execution, and adjudication. ${ }^{142}$ They did so in order to obtain other, overbalancing goods, especially public checks on private self-dealing; vigorous liberty-promoting activity by agencies; and a faster rate of policy adjustment in an ever-changing modern economy. The upshot is that invocation of the nemo iudex maxim, either in an administrative-law setting or in public law generally, is simplistic. Neither the written Constitution, nor constitutional law, nor administrative law can be successfully understood through the lens of that maxim.

\section{Conclusion: Judicial Abnegation and Administrative Due Process}

In areas of law abutting procedural due process, law has abnegated a great deal of its authority over the choice of procedures to be used in agency decisionmaking. Not all of its authority, to be sure; courts still enforce clear commands about procedure inscribed into organic statutes, and apply the general procedural rules of the APA. But courts have increasingly come to see procedure as a matter committed to agency discretion, subject only to statutory floors. In due process law itself, courts often review

\footnotetext{
${ }^{141}$ Nixon v. United States, 506 U.S. 224, 234 - 36 (1993)

${ }^{142}$ Combined at the agency head level, I mean. At lower levels, the APA creates a separation of functions between administrative law judges and prosecutorial or investigative staff within agencies. For the details, see Adrian Vermeule, Optimal Abuse of Power, Nw. U.L. Rev. (forthcoming 2015).
} 
agencies' application of the Mathews calculus, rather than simply apply the calculus for themselves.

This partial abnegation of judicial authority rests on an essentially economic and institutional insight. Judges have come to realize that agencies, even or especially when pursuing the mission that Congress has assigned to them, engage in a form of constrained optimization. Under resource constraints, agencies must design procedures with a view to substance, and vice-versa. Hence procedure and substance, whether or not conceptually distinct, are pragmatically inextricable, and agencies must calibrate both margins simultaneously. Agency authority over substance, explicitly or implicitly delegated by Congress and justified by agency expertise, necessarily implies authority over procedure as well.

The abnegation is only partial because judges retain authority to review agency procedural decisions for rationality. Agencies may not arbitrarily set procedures, but enjoy a margin of reasonable discretion in applying the Mathews cost-benefit calculus. The judges, in other words, have opted for a regime of partial administrative constitutionalism, because the judges themselves have realized, from within law, that agency procedural decisions are decisions of policy and institutional design, not subject to full legalization. On Dworkinian grounds, I suggest that this regime fits well with converging strands of caselaw and is normatively sensible. Law's Empire, here as elsewhere, has voluntarily contracted its frontiers. 